\title{
THE EFFECT OF ENGLISH SENTENCE PATTERNS AND VOCABULARY MASTERY UPON STUDENTS' ANALYTICAL WRITING SKILL
}

\author{
Hernalia Citra Dewi \\ Program Studi Pendidikan Bahasa Inggris \\ Universitas Indraprasta PGRI \\ hernaliacitradewi18@gmail.com
}

\begin{abstract}
Abstrak
Tujuan dari penelitian ini adalah untuk untuk mengetahui apakah ada pengaruh yang signifikan antara pola kalimat bahasa Inggris dan penguasaan kosakata terhadap keterampilan menulis teks analytical baik secara individual maupun simultan. Penelitian ini diadakan di SMAN 1 Cileungsi siswa kelas X1 dengan jumlah sampel 60 siswa yang diambil secara acak. Metode yang digunakan dalam penelitian adalah ex post facto. Data penguasaan pola kalimat bahasa Inggris, penguasaan kosakata dan keterampilan menulis teks analitycal diperoleh melalui test. Data dianalisis menggunakan metode statistic deskriptif, koefisien korelasi ganda, dan analisis regresi ganda. Untuk menguji statistic menggunakan uji $\mathrm{T}$ dan uji $\mathrm{F}$. hasil penelitian menyimpulkan bahwa ada pengaruh yang signifikan pada pola kalimat bahasa Inggris dan penguasaan kosakata terhadap keterampilan menulis teks analytical siswa baik secara individual maupun simultan. Hal ini ditunjukan oleh hasil regresi ganda $\mathrm{R}=0.517$ dengan kontribusi sebesar $26.7 \%$, dan Fobserved 10.386 dengan nilai sig $=0.000<0.05$.
\end{abstract}

Kata Kunci: Pola Kalimat Bahasa Inggris, Kosakata, dan Keterampilan Menulis

\begin{abstract}
The purpose of this research is to know whether there are significant effects of English sentence patterns and vocabulary mastery towards students' analytical writing skill, both individually as well as simultaneously. The research was conducted at SMAN 1 Cileungsi of eleventh grade students with the total sample 60 students that randomly taken. The method used in the research was a survey. Data of English sentence patterns mastery, vocabulary mastery and analytical writing skill were acquired from the tests. The data was analyzed using descriptive statistical method, multiple correlation coefficient, determination coefficient, and multiple regression analysis. To test the statistics is used T test and F test. The result of the research concluded that there are significant effects of English sentence patterns and vocabulary mastery towards students' analytical writing skill either individually or as well as simultaneously. It shown by the score of multiple regression $R=0.517$ with a contribution of $26.7 \%$, and $F$ observed 10.386 with a sig score $=0.000<0.05$.
\end{abstract}

Key Words: English Sentence patterns, Vocabulary, and Writing Skill

\section{INTRODUCTION}

Writing, just like other skills, is also a tool to communicate. Besides, writing is also a tool to express oneself. By writing, one can express what he feels, sees, hears, and thinks about. Even, he can write what he dreams of. To make good writing is not easy. It needs knowledge of the structure, adequate vocabulary, and specific knowledge about writing skills and writing styles. In 
addition, it needs a little knowledge about the English culture. It is important because language is a product of culture, and it grows together with the culture. Besides being a product of culture, language is also reflection of culture and society where the language is spoken, and their life style. English writing style, which originated from the AngloEuropean Culture, is direct and parallel. The Englishman writes something directly to the point. On the other hand, Indonesian people, use an indirect writing style. It means that they write something not in open and clear way. Even, it was often impressed spinning. This is due to the influence of culture towards language. Besides the difference of writing style, Indonesian language also interferes English language. In writing English, Indonesian students often simply transfer the structure of Indonesian language to English, for example: sick head for headache, art water for urine, small room for toilet, etc. Indeed, these words seem English because the words are written in English, but in fact they are not English. Based on writer's experience at a public senior high school, it shows that many students are able to communicate in English well, but only a few that are able to write in English well. It is not only because of different style of writing in English and Indonesian language, but also because of the lack of reading frequency. It is important for students to read more books or to read more often so that they are familiar with English text. In addition, the more books or the more often the students read, the more vocabulary that will be mastered. The more vocabulary students know, the more they will be able to understand what they hear and read, and the better they will be able to say what they want to when speaking or writing. Lack of writing exercises in school also contributes to this bad situation. It happens because English teacher focuses more on the English national examination that focuses only on reading and listening skill. However, students can improve their writing, like any other skill, by practicing it. English teacher should focus not only on reading and listening skill, but also in writing as well as speaking. So, hopefully the students can master all English skills. The ability to write in English has not reached the target as it should yet because of some factors such as lack of vocabulary, lack of knowledge of sentence patterns, and lack of practice. Therefore, through this research the writer wants to know if there are effects of English sentence patterns and vocabulary mastery towards student's analytical writing skill.

\section{English Sentence}

A sentence is a group of words that has a subject and a verb and expresses a complete thought (Hogue, 2003:21). It means that every sentence has two main parts: a subject and a predicate. Subject is a noun or pronoun that names who or what the sentence is about. Unlike other languages, every sentence in English must have a subject. The only exception is a sentence that expresses a command. In this kind of sentence, it is understood that the subject is you. According to Hogue (2003:22), there are two kinds of subject: a simple subject and a complete subject. A simple subject is a single noun or pronoun. While a complete subject is a simple subject followed by its modifiers. While predicate is the verb and its objects, complements, and modifiers. A predicate consists of at least a verb. In addition to a verb, a predicate may also include a direct object, indirect object, subject complement, or object complement. It may also include other 
modifiers such as expressions of time and place.

\section{1) A Declarative Sentence}

A declarative sentence makes a statement of fact or possibility. Most sentences are declarative. It ends with period. The declarative word order that we know best is the canonical order. In this order, the subject of the sentence appears first, followed by the predicate.

\section{2) An Interrogative Sentence}

An interrogative sentence asks a question. It always ends with question mark. Most interrogative sentences contain a subject-verb inversion. They may start with auxiliary verbs, interrogative adverbs, or interrogative pronouns.

3) An Imperative Sentence

An imperative sentence makes a request or gives a command. It can be ended with period or exclamation mark, depending on the urgency of the command or request. Imperative sentences can provide especially confusing word orders. Often, these sentences do not appear to contain subjects. Although the subjects may be unwritten or unspoken, they are not absent. The subjects are understood. As a command or request, an imperative sentence is always in the second person, spoken to an individual or group. Therefor we are allowed to assume the subject of an imperative sentence to be you.

\section{4) An Exclamatory Sentence}

An exclamatory sentence expresses a thought with strong emotion. It ends with exclamation mark.

\section{Problematic Sentences}

To write a correct sentence, we need to have a good understanding of what a sentence is. Students who do not have this understanding, or do not take care, often include problem sentences in their writing. Native English speakers are just as likely to write problematic sentences as ESL students. There are some common types of problematic sentence (Oshima and Hogue, 1991:169177):

\section{1) A Run-on Sentence}

A Run-on sentence is a sentence in which two or more independent clauses are written one after another without punctuation.

\section{2) A Comma Splice}

A comma splice is a sentence in which two independent clauses are incorrectly joined by a comma without a coordinating conjunction.

\section{3) A Fragment Sentence}

Fragment sentences are incomplete sentences or parts of sentences. They do not contain a complete idea. A common fragment sentence in student writing is a dependent clause standing alone without an independent clause.

4) A Rambling or Stringy Sentence

A rambling or stringy sentence is a sentence with too many independent clause, usually connected with and, but, so, and because. It often results from writing the way someone speaks, going on and like a string without an end.

\section{5) A Choppy Sentence}

Choppy sentences are sentences that are too short. Although short sentences can be effective, overuse them is considered poor style in academic writing.

\section{English Sentence Pattern}

Many people think of language use in speech and in writing as purely creative process. What they do not 
realize is that language is highly regular, almost formulaic.

Knowledge of how groups of words function to convey units or thought further enhances our ability to communicate clearly. This is why students need to know about sentence patterns, the fundamentals of how those units of thought or sentences are constructed.

English native speakers do not speak their language by just combining words in a random way, but they arrange their words into patterns. There are six basic sentence patterns in English and a large number of sub patterns. Any sentence produced by a native speaker of English or by anyone who knows the language will probably be based on one of them (Wishon and Burks, 1980):

1) Sentence pattern 1 :

Noun + Verb

2) Sentence pattern 2:

Noun + Verb + Noun

3) Sentence pattern 3:

Noun + Verb + Adverb

4) sentence Pattern 4:

Noun + Linking Verb + Noun/Adverb

5) Sentence Pattern 5:

Noun + Linking Verb + Adjective

6) Sentence Pattern 6:

Noun + Verb + Noun + Noun/Adjective

\section{English Vocabulary}

In this part the writer wants to explain the definitions of vocabulary from some references. In order to understand a language, the students have to understand the definition of vocabulary first. Vocabulary is one of the language aspects have to be learned when people are learning a language. Good mastery of vocabulary is important for anyone who learns the language that is used in listening, speaking, writing, and reading besides grammar. A learner of the foreign language will speak fluently and accurately, write easily, or understand what he or she reads or hears if he or she has enough vocabulary and has capability of using it accurately. Burton (1982) said that without a large vocabulary, it is impossible to use English language precisely and vividly. While according to Collier, when a student has mastered the fundamental grammatical patterns of language, his next task is to master its vocabulary. Thus, from the definitions above it is obvious that vocabulary is important and has important role in learning a language. Language, as quoted from Harried (2000), is a system for the expression of meaning reflected in the structure of the language as an instrument to express meaning. To understand language, we have to invent the meaning of words as many as possible either in a sentence or in a whole text. Therefore, we may not neglect the role of vocabulary. It plays an important role as a means of understanding the meaning of words precisely. Furthermore, Strumpf and Douglas (2000:431) stated that the true mark of an educated person is a welldeveloped vocabulary. Learning vocabulary is very important one in learning language. The more words the students know, the more they will be able to understand what they want to when speaking or writing. Furthermore, written language places a heavier demand on vocabulary use that does speaking. Good writers will learn to take advantage of their richness of English vocabulary (Brown: 2007).

\section{ENGLISH WRITING}

The Process of English Writing 
Writing, particularly academic writing, is not easy. It takes study and practice to develop this skill. For both native speaker and new learners of English, it is important to note that writing is a process, not a product. It means that a piece of writing is never complete. It is always possible to review and revise again and again. Many people have the mistaken idea that being able to write well is a talent that someone either has or does not have. This idea is not necessarily true. Someone can learn to write effectively if he or she is willing to learn some strategies and practice them (Oshima and Hogue: 1999).

\section{The Types of English Writing Text}

Many linguists have distinguished the writing text type into several types. Newmark in A Textbook of Translation (1988:13), for example, distinguishes writing tect type into four (literary or non-literary):

1) Narration, a dynamic sequences of events, where the emphasis is on the verbs or verbs plus verb-nouns or phrasal verb.

2) Description, which is static, with emphasis on linking verbs, adjective, adjectival nouns.

3) Discussion, a treatment of ideas, with emphasis on abstract nouns (concepts), verb of thought, mental activity (consider, argue, etc), logical argument and connectives.

4) Dialogue, with emphasis on colloquialism and phaticism.

Different from Newmark, Anita,

Gillian and Hadfield (1986: v) differentiate the writing text type into four: narrative, descriptive, expository, and argumentative. On English syllabus of senior high school, it can be seen that writing text type or genre can be divided into several, such as: narrative, spoof, recount, descriptive, report, procedure, news item, review, explanation, analytical exposition, hortatory exposition and discussion.

\section{RESEARCH METHODOLOGY}

This research used a survey method because this research was conducted to get some facts from the existing phenomenon, and to find out some factual information from population and sample of the research. A multiple linear regression technique is used to know if there are effects of student's English sentence patterns and vocabulary mastery towards his or her analytical writing skill. In this research, the writer did not do any treatment to the respondents, except giving some tests. These tests are used to get the scores of English sentence patterns mastery, vocabulary mastery, and analytical writing skill.

\section{RESEARCH FINDINGS AND DISCUSSION}

\section{The Data of English Sentence Patterns mastery (X1)}

Data of English sentence patterns mastery was taken from the test. The test composed of 30 items. Out of 60 respondents, it is known that the high scores or the correct answer is in the range 50 to 95 . Meaning that the minimum score is 50 and the maximum score is 95 . The average of all scores in a data set (mean) is 70.42 , score at center of distribution (median) 0s 70, most frequently obtained score in the data (mode) is 70 , standard deviation is 9.491 . 
Tabel 1. Mastery of English Sentence Patterns

\begin{tabular}{|c|c|c|}
\hline \multicolumn{3}{|c|}{ Statistics } \\
\hline \multicolumn{3}{|c|}{$\begin{array}{l}\text { Mastery of English Sentence } \\
\text { Patterns }\end{array}$} \\
\hline \multirow[t]{2}{*}{$\mathbf{N}$} & V alid & 60 \\
\hline & Missing & o \\
\hline \multicolumn{2}{|c|}{ Mean } & 70,42 \\
\hline \multicolumn{2}{|c|}{ Median } & 70,00 \\
\hline \multicolumn{2}{|c|}{ Mode } & 70 \\
\hline \multicolumn{2}{|c|}{ Std. Deviation } & 9,491 \\
\hline \multicolumn{2}{|c|}{ Minim um } & 50 \\
\hline \multicolumn{2}{|c|}{ Maximum } & 95 \\
\hline
\end{tabular}

Based on the statistical data above, it can be stated that English sentence pattern mastery of SMAN 1 Cileungsi is not good enough. It is indicated by the average of all data scores (mean) 70.42 .

\section{The Data of Vocabulary Mastery} (X2)

Data of student's vocabulary mastery are taken from an objective test in the form of multiple choices. The test consists of 30 items out of 60 respondents. It is known that the high scores or the correct answer is in the range 40 to 90 . Meaning that the minimum score is 40 and the maximum score is 90 . The average of all scores in a data set (mean) is 70.42 , score at center of distribution (median) is 70, most frequently obtained score in the data (mode) is 70, standard deviation is 13.879 .

Tabel 2. Matery of Vocabulary

\begin{tabular}{|c|c|c|}
\hline \multicolumn{3}{|c|}{ Statistics } \\
\hline \multicolumn{3}{|c|}{ Mastery of Vocabulary } \\
\hline \multirow[t]{2}{*}{$\mathrm{N}$} & V alid & 60 \\
\hline & Missing & 0 \\
\hline \multicolumn{2}{|c|}{ Mean } & 70,42 \\
\hline \multicolumn{2}{|c|}{ Median } & 75,00 \\
\hline \multicolumn{2}{|c|}{ Mode } & 70 \\
\hline \multicolumn{2}{|c|}{ Std. Deviation } & 13,879 \\
\hline \multicolumn{2}{|c|}{ Minim um } & 40 \\
\hline \multicolumn{2}{|c|}{ Maximum } & 90 \\
\hline
\end{tabular}

Based on the statistical data above, it can be stated vocabulary mastery of SMAN 1 Cileungsi is good enough. It is indicated by the average of all data scores (mean) 70.42.

\section{The Data of Analytical Writing Skill (Y)}

Data of Analytical Writing Skill was taken from the test. The test was just given instruction to compose Analytical Text. Out of 60 respondents, it is known that the values are in the range of 55 to 100. Meaning that the minimum score is 55 and the maximum score is 100 . The average of all scores in a data set (mean) is 74.58 , score at center of distribution (median) is 72 , most frequently obtained score in the data (mode) is 85 , standard deviation is 11.210 .

\section{Tabel 3. Analytical Writing Skill}

\begin{tabular}{|c|c|c|}
\hline \multirow{2}{*}{\multicolumn{3}{|c|}{ Statistics }} \\
\hline & & Skill \\
\hline \multirow[t]{2}{*}{$\mathrm{N}$} & Valid & 60 \\
\hline & Missing & 0 \\
\hline \multicolumn{2}{|c|}{ Mean } & 74,58 \\
\hline \multicolumn{2}{|c|}{ Median } & 72,50 \\
\hline \multicolumn{2}{|c|}{ Mode } & 85 \\
\hline \multicolumn{2}{|c|}{$\begin{array}{l}\text { Std. Deviation } \\
\text { Minimum }\end{array}$} & $\begin{array}{l}11,210 \\
55\end{array}$ \\
\hline \multicolumn{2}{|c|}{ Maximum } & 100 \\
\hline
\end{tabular}

Based on the statistical data above, it can be stated analytical writing skill of SMAN 1 Cileungsi is good enough. It is indicated by the average of all data scores (mean) 74.58.

Tabel 4. Normality Test

\begin{tabular}{|c|c|c|c|c|}
\hline \multicolumn{5}{|c|}{ One-Sample Kolmogorov-Sminnov Test } \\
\hline & & \begin{tabular}{|ll} 
Mastery of \\
English \\
Sentence \\
Pattems
\end{tabular} & $\begin{array}{l}\text { Mastery of } \\
\text { Vocabulary }\end{array}$ & $\begin{array}{l}\text { Analytical } \\
\text { Witing } \\
\text { Skill }\end{array}$ \\
\hline \multicolumn{2}{|l|}{$\mathrm{N}$} & 60 & 60 & 60 \\
\hline \multirow{2}{*}{$\begin{array}{l}\text { Nomal } \\
\text { Parameters }\end{array}$} & Mean & 70,42 & 70,42 & 74,58 \\
\hline & \begin{tabular}{|l|} 
Std. \\
Deriation \\
\end{tabular} & 9,491 & 13,879 & 11,210 \\
\hline \multirow{3}{*}{$\begin{array}{l}\text { Most Extreme } \\
\text { Differences }\end{array}$} & Absolute &, 151 &, 137 &, 159 \\
\hline & Positive & 151 &, 129 &, 159 \\
\hline & Negative & .099 &,- 137 &, 140 \\
\hline \multicolumn{2}{|c|}{ Kolm ogorov-Smimov 2} & 1,168 & 1,058 & 1,229 \\
\hline \multicolumn{2}{|c|}{ Astmp, Sig (2-tailed) } &, 130 & 212 &, 097 \\
\hline \multicolumn{5}{|c|}{ a. Test distribution is Norm al } \\
\hline \multicolumn{5}{|c|}{ b. Calculated from data. } \\
\hline
\end{tabular}


From the table we can see that all Sig value for English sentence patterns mastery, vocabulary mastery and analytical writing skill are stated consecutively by $0.130,0.212$, and 0.097. As the consequence, $\mathrm{Ho}$ is accepted. So we can conclude that all data are already distributed normally since the values of significance are all higher than 0.05 .

Tabel 5. Multicollinearity Test

\begin{tabular}{|l|l|l|l|}
\hline \multicolumn{2}{|l|}{ Coefficients } \\
\hline \multicolumn{2}{|l|}{ Model } & Collinearity Statistics \\
\cline { 3 - 4 } \multicolumn{2}{|l|}{} & Tolerance & VIF \\
\hline \multirow{2}{*}{1} & (Constant) & & \\
\cline { 2 - 4 } & $\begin{array}{l}\text { Mastery of } \\
\text { English } \\
\text { Sentence } \\
\text { Patterns }\end{array}$ &, 850 & 1,177 \\
\cline { 2 - 4 } & $\begin{array}{l}\text { Mastery of } \\
\text { Vocabulary }\end{array}$ &, 850 & 1,177 \\
\hline
\end{tabular}

Based on the multicollinearity test results in the table above is known that the tolerance score is 0.850 . it means it close to 1.0. and the Variance Inflation Factor (VIF) score is 1.177. it means that the score of both independent variable is close to 1.0. thus it can be stated that there is no multicollinearity between the English sentence patterns (X1) and vocabulary mastery (X2) in this multiple regression analysis.

Tabel 6. Galat Normality Test

\begin{tabular}{|c|c|c|}
\hline \multicolumn{3}{|c|}{ One-Sample Kolmogorov-Smirnov Test } \\
\hline & & $\begin{array}{l}\text { Unstandardized } \\
\text { Residual } \\
\end{array}$ \\
\hline \multicolumn{2}{|l|}{$\mathrm{N}$} & 60 \\
\hline \multirow{2}{*}{$\begin{array}{l}\text { Norm al } \\
\text { Parametersin }\end{array}$} & Mean & $0 \mathrm{E}-7$ \\
\hline & $\begin{array}{l}\text { Std. } \\
\text { Deviation }\end{array}$ & 9,59719867 \\
\hline \multirow{3}{*}{$\begin{array}{l}\text { Most Extreme } \\
\text { Differences }\end{array}$} & Absolute &, 187 \\
\hline & \begin{tabular}{|l|} 
Positive \\
\end{tabular} &, 187 \\
\hline & Negative &,- 094 \\
\hline \multicolumn{2}{|c|}{ Kolm ogorov-Sm imov Z } & 1,451 \\
\hline \multicolumn{2}{|c|}{ Asym 2 Sig (2-tailed) } &, 070 \\
\hline \multicolumn{3}{|c|}{ a. Test distribution is Norm al. } \\
\hline \multicolumn{3}{|c|}{ b. Calculated from data. } \\
\hline
\end{tabular}

Based on the table above, the hypothesis states that residual distribution on this regression analysis follows the normal distribution. It can be seen from $Z=1.451$ and Sig. $=0,070>$ 0,05 . It means that the assumption or regression analysis requirement is fulfilled.

\section{Linearity Test}

Linearity of Regression Line the Effect of English Sentence Patterns (X1) towards Students' Analytical Writing Skill (Y)

Tabel 7. Anova

\begin{tabular}{|c|c|c|c|c|c|c|c|}
\hline \multicolumn{8}{|c|}{ ANOVA Tahle } \\
\hline & & & \begin{tabular}{|l|} 
Sum of \\
Squares
\end{tabular} & df & $\begin{array}{l}\text { Mean } \\
\text { Squarte }\end{array}$ & $F$ & Sig \\
\hline \multirow{5}{*}{$\begin{array}{l}\text { Asalytica } \\
1 \text { Winting } \\
\text { Skill } \\
\text { Mastery } \\
\text { of } \\
\text { Engijs } \\
\text { Sentence } \\
\text { Pattems }\end{array}$} & \multirow{3}{*}{$\begin{array}{l}\text { Between } \\
\text { Groups }\end{array}$} & (Combined) & 2366,806 & 9 & 262,978 & 2,005 &, 015 \\
\hline & & Linearity & 1539,534 & 1 & 1539,534 & 15,250 &, 000 \\
\hline & & $\begin{array}{l}\text { Deriation } \\
\text { from } \\
\text { Linearity }\end{array}$ & 827,271 & 8 & 103,409 & 1,024 &, 430 \\
\hline & \multicolumn{2}{|c|}{ Within Groups } & 3047,778 & 50 & 100,956 & & \\
\hline & \multicolumn{2}{|l|}{ Total } & 7414,583 & 59 & & & \\
\hline
\end{tabular}

Based on the table 7. above, the Sig. value from Deviation from Linearity Columnis 0.430 . it means that the value is higher than 0.05 . as the consequence, $\mathrm{H} 0$ is accepted and automatically $\mathrm{H} 1$ is rejected. In other words, the regression line which indicates the effect of English sentence patterns mastery (X1) towards students' analytical writing skill (Y) is linear.

Linearity of Regression Line the Effect of Vocabulary Mastery (X2) towards Students' Analytical Writing Skill (Y) 
Tabel 8. Anova

\begin{tabular}{|c|c|c|c|c|c|c|c|}
\hline \multicolumn{8}{|c|}{ ANOVA Table } \\
\hline & & & $\begin{array}{l}\text { Sum of } \\
\text { Sourares }\end{array}$ & Df & $\begin{array}{l}\text { Mean } \\
\text { Spruare }\end{array}$ & F & Sig \\
\hline \multirow{5}{*}{$\begin{array}{l}\text { Analytical } \\
\text { Wititing } \\
\text { Skill } \\
\text { Mastery of } \\
\text { Pocsobulary }\end{array}$} & \multirow{3}{*}{ Between } & (Combined) & 2892,738 & 10 & 289,274 & 3,133 & 004 \\
\hline & & Linearty & 1195,142 & 1 & 1195,142 & 12,951 &, 001 \\
\hline & & $\begin{array}{l}\text { Deriation } \\
\text { from } \\
\text { Linesity }\end{array}$ & 1697,596 & 9 & 188,622 & 2,044 & 0,054 \\
\hline & \multicolumn{2}{|c|}{ Within Grouss } & 4521,845 & & 92,283 & & \\
\hline & \multicolumn{2}{|c|}{ Total } & $744,4,583$ & 59 & & & \\
\hline
\end{tabular}

Based on the table 8. above, the Sig. value from Deviation from Linearity Columnis 0.054. it means that the value is higher than 0.05 . as the consequence, $\mathrm{H} 0$ is accepted and automatically $\mathrm{H} 1$ is rejected. In other words, the regression line which indicates the effect of vocabulary mastery (X2) towards students' analytical writing skill (Y) is linear.

\section{INTERPRETATION OF THE RESEARCH FINDINGS}

From data description gained after analyzing the correlation, we may get the coefficient of correlation which is stated by 0.517 and coefficient of determination stated by $26.7 \%$. From the calculation by using SPSS version 20.0 for windows, it is proven that coefficient of correlation is significant. And from the regression analysis acquired the equation of regression line $\mathrm{Y}^{\wedge}=30,172+0,417 \mathrm{X} 1+0,214 \mathrm{X} 2$. It means that there is an effect of independent variable X1 (English sentence patterns) and $\mathrm{X} 2$ (vocabulary mastery) toward dependent variable $\mathrm{Y}$ (analytical writing skill). To make good writing is not easy. It needs knowledge of the structure, adequate vocabulary, and specific knowledge about writing skills and writing styles. In addition, it needs a little knowledge about the English culture. It is important because language is a product of culture, and it grows together with the culture. Besides being a product of culture, language is also reflection of culture and society where the language is spoken, and their life style. English writing style, which originated from the Anglo-European Culture, is direct and parallel. The Englishman writes something directly to the point. On the other hand, Indonesian people, use an indirect writing style. It means that they write something not in open and clear way. Even, it was often impressed spinning. This is due to the influence of culture towards language. Besides the difference of writing style, Indonesian language also interferes English language. In writing English, Indonesian students often simply transfer the structure of Indonesian language to English, for example: sick head for headache, art water for urine, small room for toilet, etc. Indeed, these words seem English because the words are written in English, but in fact they are not English. Overall, both quantitative information and theoretical review above, we can see that both English sentence patterns and vocabulary mastery altogether affect the students' analytical writing skill.

\section{CONCLUTION}

Refer to the results of hypotheses testing in Chapter IV, the writer conveys he conclusions of the research as follows:

1) There are significant effects of English sentence patterns (X1) and vocabulary mastery (X2) towards student's analytical writing skill (Y). It can be seen from Fo $=10.386$ and Sig. $0.000<0.05$. According to the multiple regression line quality, it can be stated by $\mathrm{Y}^{\wedge}=30,172+0,417$ $\mathrm{X} 1+0,214 \mathrm{X} 2$. It has meaning that 1 score increasing of English sentence patterns and vocabulary mastery variable will give 0.417 increasing to $\mathrm{X} 1$ and 0.214 to $\mathrm{X} 2$ towards the 
variable of analytical writing skill. Based on the statistical table, it can also be stated that the variable of English sentence pattern and vocabulary mastery altogether give $26.7 \%$ contribution to the variable of analytical writing skill.

2) There is a significant effect of English sentence patterns mastery (X1) towards student's analytical writing skill (Y). It can be seen from the score of $t$ observed $=2.870$ and Sig. $0.006<0.05$. Based on the statistical table 4.11 , it can also be stated that the variable of vocabulary mastery give $16.09 \%$ contribution to the variable of analytical writing skill. It means that student's English sentence patterns mastery significantly affects his or her analytical writing skill.

3) There is a significant effect of vocabulary mastery (X2) towards student's analytical writing skill (Y). It can be seen from the score of $\mathrm{t}$ observed $=2.150$ and Sig. $0.036<$ 0.05. Based on the statistical table 4.7 , it can also be stated that the variable of vocabulary mastery give $10.63 \%$ contribution to the variable of analytical writing skill. It means that student's vocabulary mastery significantly affects his or her analytical writing skill. Therefore, student's vocabulary mastery is needed to be improved in order to increase his or her analytical writing skill.

\section{REFERENCES}

Brown, H.D. (2007). Teaching by Principle: An Interactive Approach to Language Pedagogy. New York: Pearson Education, Inc.

Burton, S. H. (1982). Mastering English Language. London: The Macmillan Press Ltd.

Hogue, A. (2003). The Essential of English: A Writer's Handbook. New York: Longman.

Newmark, P. (1988). A Text Book of Translation. London: Prentice Hall International (UK) Ltd.

Oshima, A. and Hogue, A. (1999). Writing Academic English. 3rd ed. New York: Longman.

Pincas, Anita, Gillian, and Hadfield, C. (1986). Writing in English. London: Macmillan Publisher Ltd.

Wishon, G. W. and Burks, J. M. (1980). Let's Write English. New York: Litton Educational Publishing, Inc. 